\title{
Die selfverstaan van die Samaritane soos dit uit- drukking vind in die feesliturgie
} צלות מועד השמיני

\author{
J Beyers \& A P B Breytenbach \\ Departement Ou-Testamentiese Wetenskap \\ Universiteit van Pretoria
}

\begin{abstract}
The self-understanding of the Samaritans, as expressed in the liturgy of the צ'stival

This study is concerned with the identity and religion of the Samaritans. The way in which the Samaritans understood their identity is highlighted by their perception of God, by the traditions they adhered to and by the selection of texts from the Pentateuch they used in their liturgy. The beliefs and rituals of the Samaritan faith found their way into the Samaritan Liturgy. The study of a part of the Samaritan Liturgy shows that the Samaritans are heirs to the religion of the northern tribes of Israel.
\end{abstract}

\section{INLEIDING}

\subsection{Probleemstelling en verantwoording}

Hierdie ondersoek word onderneem om meer lig op die identiteit van die Samaritane te werp. Die Samaritane se geloof en godsdiensgebruike het onder andere in die Samaritaanse Liturgie neerslag gevind. Die identiteit van die Samaritane word in hierdie ondersoek belig deur aandag te gee aan-hulle Godsbegrip, die tradisies waarmee hulle hulle vereenselwig en die seleksie van Pentateug materiaal wat in die Liturgie gebruik word. Vir die doel van hierdie studie word 'n deel van die feesliturgie מוערות השמיני עצרת gebruik. Die fees wat in die Liturgie as die השמיני (Shemini Aseret) bekend staan, is die fees op die agtste dag na afloop van die Sukkot-fees (die huttefees). Die Sukkot-fees duur sewe dae vanaf die vyftiende dag van die sewende maand. Op die agtste dag van die fees, word 'n aparte fees, die Shemini Aseret-fees, gevier.

* Hierdie artikel is 'n verwerking van die resultate van 'n skripsie, ingedien en aanvaar as deel van die vereistes vir die MDiv-graad (1997), Departement Ou-Testamentiese Wetenskap, Fakulteit Teologie (Afd A), Universiteit van Pretoria, onder leiding van prof dr A P B Breytenbach. 
Rylaarsdam (1989:456) wys daarop dat die Pentateug slegs van 'n 'heilige byeenkoms' op die agtste dag van die Sukkot-fees praat (vgl Lev 23:36; Num 29:35). Die negende dag na die Sukkot-fees het later in die Joodse tradisie die fees Simchat Torah geword (Rylaarsdam 1989:456). Die Shemini Aseret-fees, wat die sewende fees van die Samaritaanse feeskalender vorm, word in die Liturgie as die 'allerheiligste van alle feeste', beskryf (Cowley 1909:782).

Hierdie ondersoek pretendeer nie om 'n dogmatiese uitleg van die Godsbegrip van die Samaritane te gee nie. Oor dié onderwerp is daar voldoende navorsing gedoen (vgl Montgomery 1968:207-215; MacDonald 1964). Hierdie ondersoek pretendeer verder nie om op grond van 'n godsdiensfilosofiese beredenering 'n vergelyking tussen die Godsbegrip van die Samaritane en die Jode te maak nie. Verder volg hierdie ondersoek nie dieselfde trajek van navorsing wat Kaiser (1993) in sy werk met die titel Der Gott des Altes Testaments gevolg het nie. Hierdie studie wil ook nie 'n geskiedenis van die Samaritaanse godsdiens gee nie. Die doel is nie om die ontwikkeling van die Godsbegrip by die Samaritane uiteen te sit nie. Hierdie ondersoek het 'n tweeledige doel. Enersyds wil dit ' $n$ bydrae lewer tot die literêrwetenskaplike ontginning van 'n deel van die Samaritaanse Liturgie. Andersyds is dit 'n ondersoek deur ' $n$ teologiese lens van 'n teks van die Samaritaanse Liturgie met die doel om tot 'n beter begrip van die selfverstaan van die Samaritane te kom.

Die Samaritane het hulle interpretasie van die Pentateugtradisies in die teks van die Pentateug bygewerk. Hierdie tendens om interpretasies akkumulerend by tekste by te werk, word by alle Samaritaanse literatuur aangetref. MacDonald (1963:4) wys daarop dat die Samaritaanse Liturgie tekste uit die Pentateug aanhaal. Die seleksie en aanwending van die tekste binne die Liturgie, kan 'n aanduiding van die Samaritane se verstaan van יהוה gee. Vandag is daar nie meer direkte toegang tot die Samaritane se verstaan van יהוה nie. Daar kan slegs op grond van die ontleding van hulle interpretasies van die Pentateug, afleidings gemaak word oor wat hulle van יהוה glo.

Van die titels en attribute wat aan יהוה in die feesliturgie van die Shemini Aseretfees toegeskryf word, is unieke titels. Die attribute van God handel oor die manier waarop die mens oor God dink en praat na aanleiding van God se ingryping in die leefwêreld van die mens. Elke volk ervaar God se ingryping anders en gevolglik praat hulle anders oor God. In hierdie studie gaan dit oor die wyse waarop die Samaritane oor יהוה praat na aanleiding van hoe hulle יהוה se ingryping in hulle geskiedenis ervaar het en daaraan neerslag gegee het in die feesliturgie van die Shemini Aseret-fees. Die oorsprong van die Samaritane is nie noodwendig die kernsaak nie. Dit gaan hoofsaaklik oor die Samaritane se selfverstaan. Dit is egter onvermydelik dat die vraag na die oorsprong van die Samaritane ook ter sprake sal kom. Coggins (1991:99) bejammer die feit dat daar oor die verband tussen die Noord-Israelitiese en Samaritaanse godsdiens geen indringende debat was nie. Tog is so 'n ondersoek na die verband tussen Noord- 
Israel en die Samaritane moeilik, omdat daar min objektiewe inligting oor die godsdiens van Noord-Israel bestaan. Die meeste inligting in die Ou Testament oor NoordIsrael is deur suidelike redaktors verwerk (Coggins 1991:101).

\subsection{Metode van ondersoek}

Aangesien die ondersoek grotendeels op 'n teksanalise staatmaak, word 'n literêrwetenskaplike benadering gevolg. Deurloo (1986:188) beskryf hierdie benadering as 'n 'synchronische benaderingswijze'. Dit wil sê dat daar nie aandag aan die historiese ontwikkeling van die teks gegee word nie, maar dat die teks, soos dit op 'n bepaalde tydstip daar uitsien, bestudeer word (Deist 1989:250). Verder word in hierdie ondersoek ' $n$ induktiewe wyse van ondersoek gevolg. Onder ' $n$ induktiewe ondersoek word verstaan: 'an argument starting from particular facts and inferring general principles from them ...' (Deist 1989:125).

Hierdie benaderingswyse het ook 'n paar leemtes. Die eerste van hierdie leemtes sou wees dat die metode nie daarvoor voorsiening maak dat die teks wat ondersoek word, ' $n$ teksedisie is nie. As gevolg van die gebrek aan toegang tot die oorspronklike manuskripte, kan die ondersoek slegs gedoen word op 'n teksedisie - 'n teksedisie wat vanselfsprekend reeds 'n geinterpreteerde teks is. Die teksedisie van Cowley (1909) word gebruik. Macuch (1991:20) beoordeel Cowley se teksedisie baie positief. Volgens hom cortref dit alle vorige edisies van die Samaritaanse Liturgie in volledigheid.

'n Tweede leemte is dat die metode nie daarvoor voorsiening maak dat die ondersoek slegs 'n ekserp van die feesliturgie van die Shemini Aseret-fees gebruik nie. Slegs die eerste paar bladsye teks in Cowley oor die Shemini Aseret-fees is vertaal en ondersoek. Die bedoeling van die ondersoek is nie om die feesliturgie van die spesifieke fees in totaliteit te ondersoek nie, maar om die selfverstaan van die Samaritane soos dit uit die geselekteerde teks blyk, na te vors.

\section{LITERÊRE ELEMENTE IN DIE SAMARITAANSE LITURGIE}

MacDonald (1963:2) beskryf die Samaritaanse Liturgie as die versameling van die Samaritaanse literatuur wat handel oor '... the beliefs of the Samaritans about the festivals; their efficacy and nature; their appearance as actual pilgrimages; the general theological system of the Samaritans; their interpretation of Biblical passages setting out the Festival laws.' Hierdie voorskrifte word op die Samaritane se verstaan van die Pentateug gefundeer. Die Liturgie bevat nie net die ordereëls vir die uitvoer van die godsdienspraktyke nie, maar ook die inhoud van baie van die godsdiensfenomene soos die gebede, himnes en skriflesings. Die inhoude van die gebede en himnes is die werk van 
verskeie Samaritaanse godsdiensleiers wat oor die eeue bygedra het tot hierdie versameling. MacDonald (1963:3) wys verder daarop dat alhoewel daar ooreenkomste tussen die Samaritaanse, Rabbynse en Karaietiese feesliturgieë voorkom, '... the Samaritan forms of worship are uniquely their own and that there has been no dependence on the liturgical forms of other faiths.'

Die Shemini Aseret-fees wat in hierdie studie ter sprake is, is deel van die Samaritaanse feeste waarvoor daar ' $n$ vasgestelde liturgie is. Cowley se teksedisie van die Samaritaanse Liturgie behandel al die rituele voorskrifte, gebede en himnes van elke fees in afsonderlike hoofstukke. Die teks van die Liturgie wat in hierdie studie onder die loep geneem word, is die eerste gebede en himnes van die fees wat in Cowley onder die opskrif צלות מועד השמיני staan (Cowley 1909:779-819).

Die Samaritaanse Liturgie was nie van die vroegste tye af in 'n gekanoniseerde vorm nie. Die teks van die Liturgie het prosesmatig oor die eeue tot stand gekom. MacDonald wys daarop dat die kern van elke liturgiese deel, die Defter is. Die Defter is die oudste laag van die Liturgie. Die latere byvoegings, wat die invloede van ander godsdienste, soos die Judaïsme, Christendom en Islam weerspieël, is die voorskrifte vir die skrifvoorlesings (die Qataf) en die liturgiese elemente wat as afsonderlike eenhede die boustene van die teks vorm. MacDonald (1963:25-44) lewer 'n breedvoerige bespreking oor elkeen van hierdie liturgiese elemente. Wat hier volg, is 'n sinopsis van die elemente wat MacDonald bespreek, met spesifieke verwysings na waar dit van toepassing is op die teks van die liturgie vir die Shemini Aseret-fees.

\subsection{Die Qataf}

Die eerste element waarvan kennis geneem moet word, is die Qataf-voorlesings. MacDonald (1963:25) wys daarop dat hierdie tegniese term wat in die Liturgie gebruik word, verwys na 'n bepaalde manier van lees van die Wet. Cowley (1909:xxii) definieer die Qataf as 'a string of phrases from the Law, connected by a common idea'. Die Qataf wat in die Liturgie voorkom, is dus 'n uittreksel van die Wet (die Pentateug) wat gekies word op grond van bepaalde kriteria.

Die liturgie van die Shemini Aseret-fees word ingelei deur 'n kort Qataf (Cowley 1909:779 reël 2): אלקטף שבת ושביצ השמיני ('Die Qataf: 'n Sabbat (soos) die sewende dag, (so is) die agtste dag.') Hierdie is 'n verwysing na Numeri 29:35 waar die voorskrifte vir die fees op die agtste dag gegee word. Vanaf reël 14 tot 17 (Cowley 1909: 779) volg 'n meer uitgebreide Qataf, waarvan die vertaling soos volg weergegee kan word: 'Verbond; en herdenking; en offergawe; en Sabbat; en die sewende dag; en Kippur; en Josef; en 'n seënwens; en 'n fees; en die plek; en eer; en 'n wolk; en vreugde; 
en 'n boom; en vrugte; en Sukkot; en die agtste dag; en Eliëser; en sy lied van die gebede.' In hierdie Qataf word die hoofelemente van die Shemini Aseret-fees weergegee.

\subsection{Die Himne}

'n Himne (MacDonald noem dit 'n shirah 1963:30) kan handel oor enige tema, of dit liturgies, teologies of misties van aard is. Die himnes in die Samaritaanse Liturgie is deur verskillende families geskryf, byvoorbeeld die Levitiese families, die Marhabifamilie en die Danafi-familie. In die liturgie van die Shemini Aseret-fees is daar 'n himne in die Kime van Murjan Ibn Al-Danafi (vgl 2.3 asook Cowley 1909:783 reël 10). Die himnes van die verskillende outeurs dateer uit die veertiende tot negentiende eeu. Elke liturg kan uit die verskeidenheid himnes wat by elke aanbiddingsgeleentheid ter sprake kom, kies watter tydens die godsdiensoefening gebruik gaan word.

Die liturgie vir die Shemini Aseret-fees bevat ook himnes. In een van hierdie himnes (Cowley 1909:779 reël 17-24) word die outeur daarvan, die hoëpriester Pinhas, vermeld. Die himne is in akrostiese vorm wat die naam van die outeur spel:

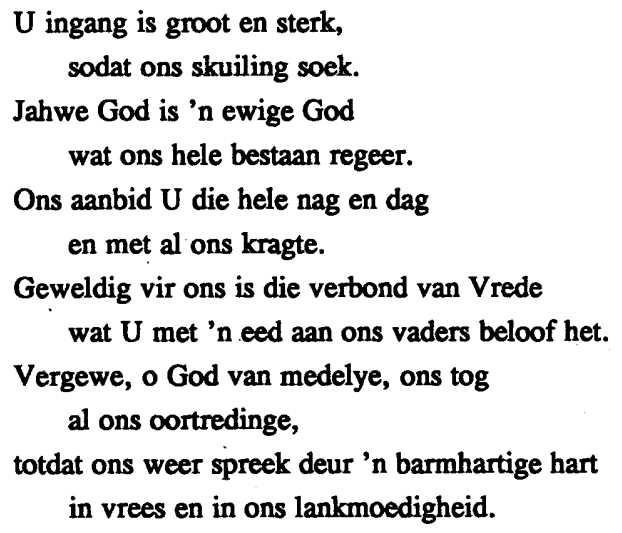

\subsection{Die Kime}

Die naam van dié tipe teks kom, volgens MacDonald (1963:33), van die woorde in Deuteronomium 11:21 כימי השמים על הארץ. Elke Kime-teks begin met hierdie woorde uit Deuteronomium. Gewoonlik word die eerste woorde van die Kime gevolg deur 'n optatiewe sin, soos dit ook die geval met 'n Kime in die liturgie van die Shemini Aseretfees is (Cowley 1909:780 reël 22): כימי השמים על הארץ תתברך ותתודי ('Solank as wat die hemel bokant die aarde is, mag $U$ geseënd en volprese wees.') Verdere kenmerke 
van die Kime-tekste is dat hulle oor die God van die patriarge praat en dan wel oor die God van Abraham, Isak, Jakob, Josef, Moses, Aaron, Eliëser, Itamar en Pinhas. Soms word die patriarge ook uitgebrei om Noag en Adam in te sluit.

Met die agtergrondkennis van die verskillende literêre elemente wat in die Samaritaanse Liturgie voorkom, is 'n studie van die Samaritaanse Liturgie van soveel meer waarde. Vanuit 'n literêrwetenskaplike oogpunt gesien, kan die literêre elemente 'n bydrae tot die verstaan van die samestelling van die Samaritaanse Liturgie lewer. Kennis van die vorm van 'n teks, dra by tot die verstaan van die inhoud van die teks.

\section{DIE GODSBEGRIP VAN DIE SAMARITANE}

MacDonald (1964:49) wys daarop dat die Samaritaanse credo in die Romeinse tyd ontstaan het en na inhoud onveranderd vir die volgende twee duisend jaar bly bestaan het. Oor die ontstaan van die credo sê MacDonald (1963:4): ' ... a creed which exhibits the evolution of North Israelite ideas and beliefs from ancient times on.' Die hoofpunte van die credo is dat die Samaritane glo in יהוה , Moses, die Heilige Wet, die berg Gerisim Bet-El en die oordeelsdag.

Die eerste drie sake van die belydenis is sake wat in die Judaïsme ook 'n belangrike rol speel. Die vierde saak van die belydenis is die rede vir die breuk tussen die Jode en Samaritane en die vyfde saak, is 'n latere byvoeging by die belydenis (Montgomery 1968:207). In hierdie ondersoek word die klem hoofsaaklik op die eerste saak in die belydenis geplaas. Die Samaritane se verstaan van יהוה word sigbaar in die wyse waarop hulle die Pentateug interpreteer.

\section{1 יהוה is Een}

Montgomery (1968:207) wys daarop dat die Samaritane se geloof in יהוה veral klem lê op 'oneness, the uniqueness, and the spirituality of God.' Green (1958:105) wys ook op die Samaritane se belydenis van יהוה se 'uniqueness and unity'. Vir die Samaritane is die een en die al wat aanbid mag word. Die belydenis oor die een-wees van יהוה word volgens Green (1958:106) en MacDonald (1964:65) gegrond op die Shema (Deut 6:4). Die swaar klem wat die Samaritaanse belydenis op die een-wees van יהוה plaas, staan polemies teenoor die Christelike belydenis van die Triniteit, wat deur die Samaritane as politeïsme geïnterpreteer word (Montgomery 1968:207). Die een-wees van יהוה, word ook in die liturgie van die Shemini Aseret-fees beklemtoon. In een van

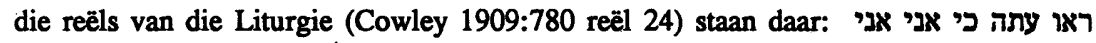
.הוא ואין אלהים צמדי Det kertaal word met: 'Besef dit nou: Ek, Ek is die Een! Naas my is daar géen ander god nie.' Hierdie is 'n direkte aanhaling van Deuteronomium 32:39. Die boek Deuteronomium speel 'n baie belangrike rol in die denke van 
die Samaritane. Bell (1994:247) sê die volgende oor die Samaritane se gebruik van Deuteronomium 32:

The song of Moses is the principal source for the Samaritan eschatology. Book 4 of the Memar Marqah is effectively a commentary on Dt. 32. Their belief in the Day of Vengeance and Recompense was based on their text of Dt. 32:35, where instead of the MT "vengeance is mine and recompense", they read "on the day of vengeance and recompense." Also central to their eschatology was Dt. 32:39, which they understood as referring to the resurrection, and other texts from Dt. 32 were also important.

In die liturgie van die Shemini Aseret-fees word die teks uit Deuteronomium 32 dus nie net in verband met die een-wees van יהוה gebring nie, maar ook met die Samaritaanse credo van die oordeelsdag. יהוה is die enigste een wat weet wanneer die oordeelsdag sal aanbreek. Sy een-wees vind ook uitdrukking in die feit dat $\mathrm{Hy}$ die enigste een is wat die einde van die tyd ken en dat $\mathrm{Hy}$ ál een is wat die eindtyd kan laat aanbreek. In die liturgie van die Shemini Aseret-fees (Cowley 1909:780 reel 25) kom die volgende uitdrukking voor: ואתה אחד לבדך ('want U is Een, U alleen'), wat warskynlik 'n sinspeling op die Shema is: שמצ ישראל יהוה אלהינו יהוה אדר (Deut 6:4). Die gebruik van die uitdrukking in die liturgie bevestig die geloof in die een-wees van יהוה?

Montgomery (1968:208) voer die oorsprong van die monoteisme by die Samaritane terug na die invloed van die Judaïsme. Maar die Samaritaanse belydenis vertoon meestal formele ooreenkomste met die bekende Islamitiese monoteïstiese uitdrukking, naamlik לית אלה אלא אחד ('Daar is geen god behalwe Allah nie.') Dié uitdrukking kom wel in die Liturgie voor en word dan in Hebreeuse letters geskryf. Green (1958: 105) argumenteer dat die Islamitiese uitdrukking gereeld in die Samaritaanse Liturgie gebruik word om die een-wees van יהוה te bevestig.

MacDonald (1964:65) wys op die vanselfsprekendheid dat die Samaritane 'n monoteistiese godsdiens bedryf: 'There is scarcely any need to point out that like Judaists, Christians and Muslims, the Samaritans are wholeheartedly monotheistic.' Die Samaritane het egter nie die Pentateug se begronding vir die monoteisme uit Deuteronomium 6:4 in hulle credo opgeneem nie, aangesien, soos MacDonald (1964:65) dit stel, die een-wees van יהוה nie deur die Samaritane net op skriftuurlike gronde aanvaar word nie. Hulle bely die een-wees van יהוה op grond van rasionele insigte. Vir die Samaritane is יהוה een, nie omdat die Pentateug so sê nie, maar omdat die heelal, mikrokosmos en makrokosmos dit bevestig (MacDonald 1964:66). 
Die Samaritane se klem op die een-wees van יהוה', word verder belig deur die volgende sinsnede in die liturgie van die Shemini Aseret-fees (Cowley 1909:781 reel 1): כי אתה אלהינו תמידה לך לבדך ('Waarlik, U is ons God; vir ewig, net U alleen'). Die teksgedeelte in die Liturgie kan moontlik 'n verwysing na Deuteronomium 10:17 wees כי יהוה אלהיכם הוא אלהי האלים ('Want Jahwe, julle God, Hy is die God van die gode').

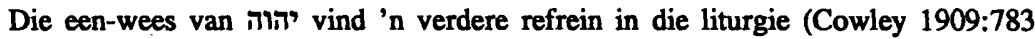
reël 19): ואתה אמרת ואין אלהים עמדי חי אנכי לעולם ואין מציל מידי (Con U het gesê: Waarlik, daar is geen God behalwe Ek nie. Ek lewe vir ewig en niemand kan uit my hand red nie'). Dié teks is 'n aanhaling uit Deuteronomium 32:39-40, maar word in omgekeerde woordorde weergegee, naamlik 32:39a; 32:40b; 32:39b. In die liturgie word die woorde so gebruik, as sou dit woorde wees wat יהוה self spreek. Hierdie is dus 'n poging om 'n onweerlegbare bewys vir die een-wees van יהוה te lewer.

Die Samaritaanse monoteistiese godsdiens is natuurlik nie Samaritaanse Sondergut nie. Die monoteistiese godsbegrip van die Samaritane kom, volgens Green (1958:106), uit die Pentateug. Die Samaritane het soos Israel 'n sterk monoteïstiese geloof. Green (1958:106) beskryf die invloed van die Islamitiese idees oor monoteisme, soos volg:

While it may be argued that in some cases epithets referring to the One God may be the result of Islamic influence, it is quite clear that this is purely terminological dependence, the basic thought of the Unity of God rests on a common Jewish-Samaritan concept which owes no dependence to any other source than the revelation given to Israel.

Hiermee verwerp Green die moontlikheid dat die Islamitiese denke invloed op die vorming van die Samaritaanse monoteïstiese Godsbegrip kon hê. Die oorsprong van die monoteistiese Godsbegrip van die Samaritane moet dus eerder by die inter-afhanklikheid van Israel en die Samaritane gesoek word.

\section{2 יהוה die Skepper}

Die Samaritaanse skeppingsleer stel dat יהוה die Skepper van alle dinge is. Volgens Marqa, die groot Samaritaanse teoloog, bestaan alle materie uit die elemente vuur, wind, water en grond. Die liturgie van die Shemini Aseret-fees het 'n verwysing na dié vier kemelemente (Cowley 1909:782 reël 28): היא כארבע אקרי הברי ('Dit is soos die vier wortels van die skepping'). Die uitnemendheid van die vier feeste in die sewende maand (naamlik die heilige byeenkoms op die eerste dag van die sewende maand, die 
Groot Versoendag op die tiende dag van die maand, die huttefees vir sewe dae lank vanaf die vyftiende dag van die sewende maand en die Shemini Aseret-fees op die agtste dag van die huttefees) word vergelyk met die vier kernelemente van alle materie.

Adam is die eerste mens wat geskape is en het gewoon in die Eden-tuin. Die liturgie ויטצ יהוה : אan die Shemini Aseret-fees verwys na dié tuin (Cowley 1909:780 reël יהוiה God het die tuin van Eden in die Ooste geplant'). MacDonald (1964:117) voer aan dat die Samaritaanse skeppingsleer sterk op die Priesterlike bron se weergawe van die skeppingsverhaal in die Pentateug steun. Daaruit maak MacDonald (1964:117-118) sekere afleidings wat die identiteit van die Samaritane betref:

We cannot enter here into the question whether $P$ is a document from northern Israel and therefore with Samaritan Israelite affinities, but it is to be noted that the only Hexateuchal document that is manifestly southern in origin, namely $\mathrm{J}$, is the only one that the Samaritan thinkers had least concern for.

Dit is dus moontlik dat die Samaritaanse skeppingsleer in die trajek van 'n NoordIsraelitiese tradisie lê. יהוה self is die bron en die wese van alles wat geskape is (MacDonald 1964:119). Daaruit volg dat יהוה die enigste Skepper kan wees. Hierdie gedagte kom ook in die liturgie van die Shemini Aseret-fees voor (Cowley 1909: 780 reël

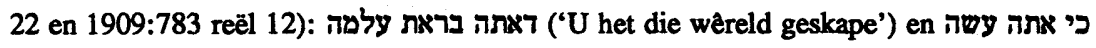
העולם ('U wat die heelal gemaak het').

Die skeppingsmag van יהוה vloei uit sy almag voort. Die Een wat alles geskape het, heers ook oor alles en almal. Hierdie gedagte kom in die liturgie van die Shemini כי אתה : Aseret-fees pertinent na vore en wel soos volg (Cowley 1909: 783 reël 16-17) מלוך לעל ולרצ והפאות הארבה וצוד לבדך עבוד בריאתה וכל רבה geerder oor alles en almal en oor die vier uithoeke van die aarde. En altyd is dit U alleen wat aanbid word deur die hele skepping en alles wat daarin is').

Deur יהוה as Skepper te erken, gee die Samaritane toe dat hulle onderdane van יהוה is. Kaiser (1993:91) maak die volgende opmerking oor die verhouding Skepper teenoor skepsel soos wat dit by die volk Israel voorkom: 'Trotzdem bleibt es auffällig, dass sich die Alten nicht als Schöpfer, sondern als Geschöpfe der Götter verstanden, deren Herrschaft sie sich ausgesetzt wussten.' 


\section{3 יהוה is ewig}

יהוה as die Skepper is nie self gebind deur tyd en plek nie (MacDonald 1964:69). Hy is onmeetbaar en dus oneindig, van ewigheid tot ewigheid (MacDonald 1964:71). Laasgenoemde gedagte word bevestig in die liturgie van die Shemini Aseret-fees (Cowley 1909:779 reël 1): בשמו נשרי ונחסל ('In sy Naam; [Hy wat] die begin en die einde is'). יהוה word hier besing as die Een wat die begin en die einde van alle dinge is. Wanneer daar oor die ewigheid van geen beginpunt vir sy ontstaan is nie en geen eindpunt wanneer Hy sal ophou bestaan nie. Dieselfde gedagte word in die Liturgie herhaal (Cowley 1909:779 reel 20): יהוה אל קדום (יהוה is 'n ewige God').

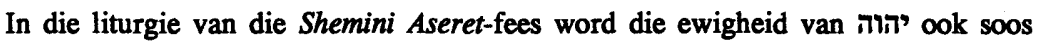
volg beskryf (Cowley 1909:780 reël 26-27): ואתה אמרת על גדלך חי אנכי לעולם ('Uself het oor u grootheid gesê: So waar as wat Ek vir ewig lewe'). Hierdie direkte aanhaling uit Deuteronomium 32:40 is woorde wat deur die outeur in die mond van gelê word om sodoende 'n onweerlegbare bewys vir sy ewigheid te gee. Dieselfde gedagte kom ook nog in reël 29 voor (Cowley 1909:780): וחיי עולם רילך ('en die ewige lewe is u s'n').

'n Verdere perspektief op die ewigheid van יהוה word in die liturgie van die Shemini Aseret-fees aangetref (vgl bv Cowley 1909:782 reël 2 en 1909:783 reël 9 en 1909:784 reël 21). Die woorde ('Ek is wat Ek is') uit Eksodus 3:14, word telkens as ' $n$ afsluitingsformule an die einde van liturgiese dele gebruik. MacDonald (1964:71) sê die herhaalde gebruik van hierdie uitdrukking word deur die Samaritane geïnterpreteer as 'n verwysing na die ewigheid van יהוה. Dit sou volgens hulle beteken: 'eternal; everlasting; unending; unbegun; unended' (MacDonald 1964: 71). Die Samaritane se persepsie van יהוה is dus: die Een wat geskep het, is self nie geskep nie en Hy hou self ook nie op om te bestaan nie.

\section{4 יהוה is die Almagtige}

Die almag van יהוה staan vir die Samaritane in verband met verskeie attribute en eienskappe van יהוה. Omdat daar maar een soos יהוה is (vgl 3.1), is Hy die Almagtige. Green (1958:108) stel die saak soos volg: "There can be no doubt that the Samaritan trust in God is bound up with his firm conviction of God's supremacy. The work of creation is a demonstration of God's power but it is believed that this power is active in other ways as well.' Montgomery (1968:210-211) vestig weer die aandag op die Samaritane se idee van die onvergelykbaarheid van יהוה: '... the Samaritan theology dwell upon the incorporeality and impassibility of God ...'. In die liturgie van die Shemini כי אתה צשה : Aseret-fees word verwys na die onvergelykbare wyse waarop יהוה 
העולם בלא כלי ולא יד ('U het die wêreld geskape, nie deur 'n gereedskapstuk nie, en nie deur 'n hand nie') (Cowley 1909:783 reêl 12-13).

Die almag van יהוה beteken vir die Samaritane ook dat יהוה die een is wat polities oor hulle regeer. MacDonald wys daarop dat die Samaritane alle mag en heerskappy aan יהוה toeskryf, want 'there was no Samaritan ruler over Samaria for so many centuries that it became regular practice to attribute the rulership of the land and of course, everything else to God' (MacDonald 1964:74). Die Samaritane het dus onder 'n sterk teokratiese heerskappy gestaan. Hierdie gedagte kom in die liturgie van die Shemini Aseret-fees ook voor (Cowley 1909:783 reêl 13) אלהי הכל אתה למר ('Die God van die heelal is U'), en (Cowley 1909:783 reël 16 ('want U is die regeerder oor alles en almal')

Volgens MacDonald (1964:78) is dit eintlik onvermydelik om oor 'n godheid te praat sonder die gebruik van attribute: 'It is always difficult to avoid describing the activities of God in terms of his attributes; every Near Eastern religion has this problem.' Montgomery (1968:214) wys ook op die feit dat alhoewel die Samaritaanse godsdiens 'n monoteistiese godsbegrip het, daar 'n groot verskeidenheid titels en eienskappe gebruik word om 'הוה te beskryf. Ook die liturgie van die Shemini. Aseret-fees skiet nie aan attribute vir יהוה tekort nie. 'n Paar van die algemene attribute wat vir יהוה in die liturgie van die Shemini Aseret-fees gebruik word, is:

* יהוה המיטב המרוח ('Jahwe die Goeie en die Verhewene') (Cowley 1909:779 reäl 1). Dit is waarskynlik 'n sinspeling op Eksodus 33:19.

* חילה דבחר אדם ('Die kragtige Een wat die mens uitkies') (Cowley 1909:780 reël 3). Die Samaritane, sê MacDonald (1964:78): '.. do not hesitate to express the power of God in terms of "the powers above", by which is meant the angelic hosts who are ever at hand to work God's purposes out.'

* אל קנא ('die jaloerse God') (Cowley 1909:780 reël 9). Die uitdrukking is 'n sin-

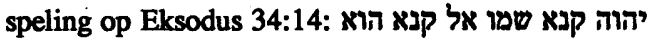

* דאתה מסחן אלהותה ('want U is die Besitter van Goddelikheid') (Cowley 1909:780 reël 29).

* ראתה אלהי האלהים ('want U is die God van die gode') (Cowley 1909:781 reël 23). Hierdie uitdrukking verwys in alle waarskynlikheid na Deuteronomium 10:17: יהוה אלהיכם הוא אלהי האלהים. 
* אל אלהי הרוחות לכל הבשר ('God, die God van die geeste van alle vlees') (Cowley 1909:783 reël 22). Hierdie sitaat uit Numeri 16:22 kom twee keer in die liturgie van die Shemini Aseret-fees voor. Dit sou 'n sinspeling kon wees op die wonder by die Rietsee waar die wind die waters geskei het en Israel op droë grond deurgetrek het (Eks 14:21; 15:8; vgl ook אלהי הרוהות ['die God van die winde/ geeste'] in Cowley 1909:782 reël 16).

Die almag van 'יהוה staan in verband met 'n verdere eienskap. Die Samaritane heg die meeste waarde aan die liefde van יהוה. Met die terme van Eksodus 34:6, word יהוה as die 'genadige en barmhartige God' beskryf. Dié attribute kan ook, volgens Montgomery (1968:213), teruggevoer word na Islamitiese invloed, omdat dié terme in elke inleidingsformule van al die Surahs in die Koran voorkom. In die liturgie van die Shemini Aseret-fees kom die uitdrukking in die vorm יהוה אל רחום וחנון ('Jahwe is die genadige en barmhartige God') voor (Cowley 1909:779 reël 9).

\section{SELFVERSTAAN}

Jeismann (1985:13) wys op die verskillende funksies van geskiedenisvertelling. Een van die funksies is identiteitvinding. 'n Groep of indiwidue vertel hulle verlede oor om hulle unieke identiteit aan hulleself en aan ander te bevestig en die konstante onveranderlike van hulle identiteit aan te dui (Jeismann 1985:13). Die manier hoe 'n volk hulle verlede oorvertel, grens hulle van ander volke af. Die manier hoe die Samaritane hulle voorvaders in hulle tradisies weergee, dui aan hoe die Samaritane hulle eie identiteit verstaan.

'n Tweede funksie van geskiedenisvertelling, is om 'n saak of aanspraak in die hede te legitimeer. Dit word gedoen deur die verlede op 'n bepaalde manier oor te vertel (Jeismann 1985:14). Dit geld ook vir genealogiese lyste. 'n Volk of groep se genealogie word gewoonlik op so 'n manier ingeklee dat hulle aansprake in die hede gelegitimeer word. Wanneer die Samaritane hulle vereenselwig met bepaalde voorvaders, 'n spesifieke priesterlyn en sekere feeste, dan het die oorvertel van hulle verlede ook 'n identiteitstigtende en legitimerende funksie. Deur die tradisies oor die voorvaders, die priesterlyn en die feeste van die Samaritane te ondersoek, word die identiteit van die Samaritane duideliker belig.

\subsection{Die Voorvaders}

Die Samaritane aanbid nie 'n ander God as hulle voorvaders nie. Hulle godsdiens is volgens hulle die voortsetting van 'n lang tradisie. Die liturgie van die Shemini Aseret- 
fees bevestig dit: כי אתה אלהינו ואלהי אבותינו ('U is ons God en die God van ons vaders') (Cowley 1909:783 reël 23); ואלהי אבותינות ('die God van ons vaders') (Cowley 1909:781 reël 4; vgl ook 783 reël 24).

In twee Kime's in die liturgie van die Shemini Aseret-fees ('n gedig van Sa'd adDin - Cowley 1909:781 reël 6 - 782 reël 2, en 'n Kime van Murjan Ibn Ibrahim AlDanafi - Cowley 1909:783 reël 10 - 784 reël 22) word die voorvaders van die Samaritane besing as diensknegte van יהוה. In die gedig van Sa'd ad-Din, word die volgende patriarge genoem: Abraham, Isak, Jakob, Josef, Moses, Aäron, Eliëser, Itamar, Pinhas, Josua en die seun van Jefunne. Al-Danafi noem die volgende groep: Die Seun van die Eufraat, die profeet (Moses), Aäron, Eliëser, Itamar en Kaleb die seun van Jefunne. Montgomery (1968:231) sê dat die rol wat die patriarge in die Samaritaanse teologie speel, bloot dié is van 'regverdiges'; hulle is diegene wat sonder skuld is; diegene wat eerbaar is. Tradisioneel is die Samaritaanse patriarge Abraham, Isak en Jakob. 'This number is also enlarged so as to obtain the mystical seven, but the list varies' (Montgomery 1968:231). Die lys van patriarge word daarom ook soms aangevul om die name van Josef, Aäron, Eliëser, Pinhas en Moses in te sluit (Montgomery 1968:231).

Die aansien wat Abraham volgens Joodse en Islamitiese tradisies geniet (vgl Surah XIV in die Koran), ontbreek by die Samaritane. Montgomery (1968:231) wys op Abraham se sekondêre rol, teenoor Moses die godsdienstige leier. In verband met die patriarge Abraham, Isak en Jakob sê MacDonald (1964:16) dat die Samaritane hulle eie ontstaan terugvoer na die drie patriarge: '... the time of the Patriachs, the righteous three as they are usually described, Abraham, Isaac and Jacob. Joseph is added to these, but the essence of the Samaritan conception is understood in terms of God's covenants with the righteous three.'

Marqa, die Samaritaanse teoloog, vertel dat Isak op die berg Gerisim geoffer is (Montgomery 1968:231). In hierdie opsig verskil die Samaritaanse tradisie van die Pentateug tradisie wat se dat Isak op ' $n$ berg in die landstreek Moria geoffer is.

Josef is in die Samaritaanse teologie 'n meer prominente figuur as wat hy in die Judaïsme is. In die Samaritaanse tradisie word aan Josef selfs die titel 'koning' toegeken (MacDonald 1964:74; Kippenberg 1971:256). Die besitters van die grond rondom Gerisim is nie net die Josef-familie nie, maar die hele stam van Josef. Verder glo die Samaritane dat dit net Josef en die Josef-stam is wat waarlik gehoorsaam gebly het aan Moses se bevele: 'Was Mose befahl, kann allein Joseph ausführen' (Kippenberg 1971:260). Die konklusie waartoe Kippenberg kom, is dat Josef egter nie so 'n prominente rol in die Samaritaanse teologie speel soos Moses nie: 'Der Glaube an Mose ist 
im samar. Credo dogmatisiert, ohne dass auch nur kleinste Ansätze für eine gleiche Würdestellung Josephs zu entdecken sind' (Kippenberg 1971:262). Josef word egter binne die Samaritaanse denke as die heerser van die komende ryk beskou (Kippenberg 1971:268). Hy is, as die komende Samaritaanse heerser, deel van die Samaritaanse eskatologiese verwagtinge. Oor die gebruik van die naam van Josef, maak Wintermute die opmerking dat die naam van Josef in die Bybelse literatuur soms na die stam van Efraim alleen (Num 1:32), of die stam van Manasse alleen (Num 36:1), of die stamme van Efraim en Manasse saam, of die Noordryk, of na al die Israeliete (Ps 80:1), verwys.

Moses, as een van die patriarge, speel 'n baie prominente rol in die Samaritaanse denke. 'Moses was the sole medium of God's revelation' (Montgomery 1968:225). Moses is die een wat die Wet van God aan die mense bekendmaak. Oor die Samaritaanse oortuiging dat die Wet onfeilbaar is, sê Green (1958:114-115): 'It is the holiest of books. It contains commandments and statutes and precepts and decrees ... It is the boast of the Samaritans that they keep the Law more exactly than the Jews.' Die een wat die Wet bring word cok as onfeilbaar beskou. Die gevolg is dat Moses meer is as 'n patriarg: '...[T]he Samaritan advances the great Lawgiver to a position where he becomes an object of faith. He is rather like the Christ of Christianity ...' (Montgomery 1968:225).

Josua, die opvolger van Moses, vestig die Israeliete in Kanaän en ken aan elke stam die grondgebied toe soos Moses hom beveel het. Die sentrum waarvandaan Josua die land volgens Samaritaanse tradisie regeer, is Sigem (MacDonald 1964:16), geleë tussen die berge Gerisim en Ebal. Josua en Kaleb, die seun van Jefunne, word deel van die lys van patriarge op grond van hulle voorbeeldige lewe op aarde.

Van die name wat in die Samaritaanse lys van patriarge voorkom, se MacDonald (1964:317), is juis gekies op grond van hulle goeie en vroom lewe. In hulle aardse lewe, sê MacDonald (1964:277, 317), het hierdie manne 'n goeie daad gedoen wat 'n aanduiding was dat יהוה hulle uitgekies het om hulle te seên. Johnson (1989:483) argumenteer dat Kaleb nie 'n egte Hebreër was nie, maar wel van Edomitiese afkoms. Binne die Samaritaanse denke is die persone in die Pentateug wat 'n goeie en vroom lewe gelei het, opgeneem as deel van die patriarge en daarom hoef daar nie 'n besondere binding tussen Kaleb en die Samaritane gesoek te word nie.

\subsection{Priesterskap}

Priesterlike aansprake, genealogieë en die geskiedenis van die priesterskap, is altyd 'n baie subjektiewe saak wat deur elke groep suiwer tot sy eie voordeel corgelewer word. Wellhausen (soos aangehaal deur Cross 1980:195) se rekonstruksie van die geskiedenis 
kom daarop neer dat die priesterskap in Israel deur 'n lang ontwikkelingsproses gegaan het. Hierdie proses kan in drie fases verdeel word: 'n fase waar daar geen oorerflike priesteramp was nie, 'n fase gedurende die koningstyd waarin die Levitiese priesterskap in Jerusalem begin figureer, en die post-eksiliese teokratiese fase van die Aăronitiese priesterskap. Bowman (1959b:43) sien die saak van die Samaritaanse priesterskap soos volg: 'The Samaritans claim that their priests are described from Aaron; at least they are of Zadokite stock, presumably descended from the Jewish post-exilic Zadokite High Priest Eliashib of Jerusalem whose grandson married Sanballat's daughter and was sent apacking from Jerusalem by Ezra'.

Die Samaritane self voer natuurlik die oorsprong van hulle priesterskap na Aäron terug via sy kleinseun Pinhas wat op die berg Gerisim 'n heiligdom gevestig het (MacDonald 1964:16). Volgens húlle tradisies het Aäron die priesteramp verdeel tussen sy twee seuns: aan een het hy die hoëpriesterlike amp toegesê en aan die ander die hoofskap oor die Levitiese groep. Pinhas, die seun van Eleaser, word die erfgenaam van die hoëpriesteramp op grond van sy weldaad (volgens Num 25:7-8) waarvan daar ook in die liturgie van die Shemini Aseret-fees sprake is (Cowley 1909:781 reël 26). Die Samaritaanse weergawe van Eleaser se aanwysing as hoëpriester, stem ooreen met die Pentateug weergawe (Num 20:25-28).

Die Samaritane glo dat Eli, 'n afstammeling van Itamar, die hoëpriesteramp selfsugtig nagejaag het (MacDonald 1964:17). Eli het na Silo verhuis en daar 'n heiligdom wat kompeterend met die heiligdom op Gerisim was, opgerig. 'Thus for a time the Israelites had two sanctuaries and two priesthoods (one descended from Phinehas, the other from Ithamar)' (MacDonald 1964:17). Die Samaritane glo dus dat die Judaïsme as ' $n$ dwaling by Eli begin het en dat die Samaritane die ware priesterskap en ware leer handhaaf. MacDonald (1964:17) meen dat dit die eerste tekens van 'n breuk in Israel is. Tog is dit belangrik dat dié eensydige Samaritaanse argument nie as die enigste waarheid voorgehou kan word nie ( $\mathrm{vgl}$ in dié verband die verskillende weergawes oor die ontstaan van die Samaritane in Beyers \& Breytenbach 1995:901).

Die Samaritaanse gebruik dat die koning priesterlike funksies vervul, vind ook neerslag in die liturgie van die Shemini Aseret-fees. MacDonald (1964:74) sê die volgende oor dié gebruik:

Kingship in Samaritan eyes was therefore something special. According to their chronicles king and priest worked together in the early history of the Israelites in Canaan .... The association of the rulership with the priesthood is a characteristic of the Samaritans' historical concept and 
probably is to be explained thus: there could be no supreme ruler who was not specially appointed or ordained (anointed).

Gaster (1913:198) wys op die verskille tussen gebruike van die huttefees soos wat dit in Juda en in die Noordryk bestaan het. Jerobeam, die koning van die Noordryk, het volgens 1 Konings 12:31-33 self die offer op die altaar gebring. Afgesien daarvan dat Jerobeam 'n ander tradisie oor die offer-rituele as die Judeërs gevolg het, het Jerobeam ook die huttefees in die Noordryk na die agtste maand aangeskuif.

In die liturgie van die Shemini Aseret-fees word die ritueel rondom die eerstes van die oes wat in Deuteronomium 26 voorgeskryf word, in 'n gewysigde vorm aangetref. Volgens Deuteronomium 26 is dit elke Israeliet se plig om self die mandjie na die priester te neem. In die Liturgie (Cowley 1909:782 reël 34-783 reël 9 en ook Cowley 1909:791, 792, 793, 795, 812) word die ritueel van die eerstes van die oes beskryf. Telkens is dit die מלך ישראל 'koning van Israel' (Cowley 1909:782 reël 34) wat die mandjie met vrugte voor die priester moet neersit. Dit is nie vreemd dat 'n koning 'n offer na die altaar bring nie. De Vaux (1988:113-114) wys daarop dat daar genoegsame voorbeelde is waar konings van die Suid- sowel as die Noordryk offers op die altaar gebring het. Met die opmerkings van Gaster (1913) in gedagte en die teks van die Liturgie (Cowley 1909:782) voor hande, is dit duidelik dat die Samaritane hier 'n ander interpretasie van Deuteronomium 26 huldig, dalk in navolging van die gebruik van Jerobeam (vgl 1 Kon 12).

\subsection{Feeste}

In die liturgie van die Shemini Aseret-fees word al die feeste wat die Samaritane vier, genoem. Die Shemini Aseret-fees, die 'sewende fees' op die Samaritaanse kalender, word in die Liturgie as die 'allerheiligste dag' besing: שיצ מוצדיה וקדש קדשיה (Cowley 1909:780 reël 15, 782 reël 32). Die feeste van die Samaritane, volgens die liturgie van die Shemini Aseret-fees, is die volgende (Cowley 1909:782 reël 11-783 reël 9):

* Die eerste fees: In die eerste maand word die pasga (הפסח) gevier. Tydens die fees word die verlossing van Israel uit Egipte herdenk.

* Die tweede fees: In die tweede maand word Israel se deurtog deur die see herdenk. 
* Die derde fees: In die derde maand word die openbaring by Sinai herdenk.

* Die vierde fees: Op die eerste dag van die sewende maand (חרש השביצי) is daar 'n heilige byeenkoms.

* Die vyfde fees: Op die tiende dag van die sewende maand is dit die Groot Versoendag (יום הכפור).

* Die sesde fees: Vanaf die vyftiende dag van die sewende maand vir sewe dae lank word die huttefees (הג הסכות) gevier.

* Die sewende fees: Op die agtste dag van die sewe dae lange huttefees is dit die Shemini Aseret-fees (יום השמיני עצרת).

Die feeste van Israel het 'n lang ontwikkelingsgeskiedenis. In verskillende stadia van die geskiedenis van Israel, is die feeste op verskillende maniere ingerig. So byvoorbeeld kon in 'n sekere stadium van die geskiedenis van Israel die huttefees wel 'n landboufees gewees het (Eks 34:22). Dit het later 'n herdenkingsfees van 'n historiese gebeurtenis geword (Lev 23:43). Die verpligte feeste van die Israeliete was volgens De Vaux (1988:484-515):

* die paasfees (הפסח); ook genoem die fees van ongesuurde brood (חג המצות)

* die fees van die weke (חג השבעות); ook die fees van die oes (Eks 23:16) of pinksterfees (Hand 2:1) genoem

* die huttefees (תס הסכות); ook genoem die fees van insameling (Eks 34:22).

Daarbenewens was daar ook die volgende feeste: Die dag van die Groot Versoening (יום הכפור); die sabbat; die nuwemaanfees; die sabbatjaar; die hersteljaar; die Nuwejaarsfees en die Purimfees. Die feeste wat die Jode en die Samaritane vier, verskil in geringe mate van mekaar. Die eerste fees van Israel en die Samaritane is die pasga. Albei groepe voer die corsprong van hierdie fees tot dieselfde heilsdaad terug, naamlik die verlossing uit Egipte. Die pasga is selfs vandag nog vir die Samaritane een van die belangrikste feeste (Kraus 1966:54). Die fees van ongesuurde brood wat volgens Deuteronomium 16:1-8 saam met die pasga een fees is, word deur die Samaritane as 'n aparte fees gevier. In navolging van Eksodus 23:15 vier die Samaritane die fees van ongesuurde brood om die uittog uit Egipte te herdenk (Cowley 1909:794 reel 6). 
Die derde fees van die Samaritane en die tweede fees van Israel hou verband met mekaar. Die fees van die weke (חג השבעות), ook die oesfees genoem (Eks 23:16), het vyftig dae na die fees van ongesuurde brood (Lev. 23:16) of sewe weke na die koringoes (Deut 6:9) aangebreek. Vir Israel was die fees van die weke dus 'n landboufees. Eksodus 19:1 verbind die Sinai-episode met die fees van die weke wat in die derde maand gevier is. Kraus (1966:591) wys daarop dat die verbintenis tussen die fees van die weke en die wetsopenbaring op Sinai op 'n ouer tradisie gebaseer is. Die tradisie wat in 2 Kronieke 15:10-14 weerspieël word, stel dat die fees van die weke na die verbondsvernuwing teruggaan. Die voorlesing van die wet op Sinai en die verbondsvernuwing kan met mekaar in verband gebring word. Die Samaritaanse Liturgie (Cowley 1909:782 reël 16) weerspieël die tradisie wat in Eksodus 19 opgeneem word waar die fees van die weke met die wetsopenbaring by Sinai verbind word.

Die vier feeste wat volgens die Shemini Aseret-liturgie tydens die sewende maand gevier word, het hulle ekwivalente in die Joodse feeste: Die eerste dag van die sewende maand is 'n heilige byeenkoms (Lev 23:24 en Num 29:1); die tiende dag van die sewende maand is die Groot Versoendag (Lev 23:27 en Num 29:7); vanaf die vyftiende dag van die sewende maand word die huttefees vir sewe dae lank gevier (Lev 23:39); op die agtste dag van die huttefees is dit die Shemini Aseret-fees. Volgens Levitikus 23 is die eerste en die agtste dag van die huttefees 'n feesdag. Rylaarsdam (1989:456) wys daarop dat die huttefees deur twee ekstra feesdae opgevolg is. Die agste dag is as feesdag gevier en die negende dag het die Simchat Torah-fees geword.

Die Israeliete kon in hulle berekening van die korrekte datum vir 'n fees 'n lenteof herfskalender gevolg het. Die Samaritaanse Liturgie gee die pasga as die eerste fees van die kalenderjaar aan en gee daarmee 'n aanduiding dat 'n lentekalender gevolg word. Die eerste dag van die sewende maand het in latere tradisies die nuwejaarsfees geword (De Vaux 1988:502). As die nuwejaarsfees in die herfs (die sewende maand) as die eerste fees van die jaar aangedui sou word, dan sou die herfskalender gevolg word. De Vries (1989:484) voer aan dat 'n herfskalender oorwegend in Juda gevolg is en dat Jerobeam in die noorde die lentekalender gevolg het. Die Samaritaanse affiniteit vir die gebruike van die Noorde verklaar waarom die Liturgie 'n lentekalender weerspieël.

Die Samaritaanse feeste bestaan volgens Green (1958:viii) uit drie pelgrimsfeeste, naamlik die fees van ongesuurde brood, die fees van die weke en die huttefees. Bowman (1959b:43) verduidelik: :Once a year at Passover sacrifice is performed; and three times a year, at the Feast of Unleavened Bread, of Pentecost and of Tabernacles, pilgrimage is made to the top of the mountain.' Al drie hierdie feeste word deur die term ג gekwalifiseer om aan te dui dat dit handel oor feeste wat met 'n pelgrimsreis na die 
berg Gerisim, gepaard gaan. Tydens die ander feeste word geen pelgrimsreis onderneem nie. Green (1958:9) wys ook daarop dat die sewedaagse huttefees deur 'n agste feesdag gevolg word: 'An eighth day has also been added, an innovation, which like the first day, is marked by a solemn rest. This is a concluding feast to round of the celebrations ....'

Die Shemini Aseret-fees is nie eksklusief 'n Samaritaanse fees nie. Die fees word vandag nog deur die Jode gevier. Epstein (1959:173) verduidelik hoe die Jode in die moderne tyd die fees vier:

As the season of vintage, the dominant note of the festival is joy .... But the joy is infused with deep religious sentiments and is bound up with the study of the Torah. This spirit is carried over to the closing festival on the eighth day, Shemini Atzereth, which since the ninth century has become connected with the 'Rejoicing of the Law' (Simchat Torah) on the ninth day ... In Palestine, where there is no ninth-day celebration, the 'Rejoicing of the Law' takes place on the eighth day.

Die derde fees wat die Liturgie identifiseer as die fees wat in verband met die wetsopenbaring op Sinai staan, was waarskynlik 'n verbondsvernuwingsfees in Sigem. Wright (1962:59) stel dit soos volg:

On the other hand, to me it appears possible that at one time in North Israel the covenant-renewal celebration was revised and turned into a penitential service by the use of the rib motif. This involves an acceptance of Von Rad's arguments concerning the liturgical elements in Deuteronomy, their origin in North Israel (see also A C Welch and others), and the existence there of a covenant-renewal ceremony, originally celebrated at Shechem.

\section{DIE ROL VAN GESELEKTEERDE TEKSTE UIT DEUTERONOMTUM IN DIE SAMARITAANSE LITURGIE}

Labuschagne (1971:85) is, in navolging van die tradisie van Noth, van mening dat Deuteronomium 32 saam met Deuteronomium 31-34 as 'n latere byvoeging tot die boek Deuteronomium beskou moet word. Labuschagne (1971:86) stel voor dat Deuteronomium 32 gesien moet word as deel van die geskiedenis van die laaste dae van Moses wat reeds begin by Deuteronomium 29, die verbondsluiting in Moab. 
Wat die ouderdom van Deuteronomium 32 betref, stel Wright (1962:38) 'n datering van ongeveer 1070-1020 vC voor. Wright glo dat die gedig sy oorsprong het by die noordelike stamme (moontlik Efraimities of Benjaminities) wat teen die Filistyne in die Rigtertyd geveg het. Die gedig is deur die Elohis opgeneem en deel van sy korpus gemaak (Wright 1962:38). Luyten (1985:347) glo weer dat die breẽ raamwerk van Deuteronomium 32 tot 'n ouer gedig wat eintlik 'n rib teen Israel was, behoort het. Die finale redaktor het elemente uit hierdie ouer gedig geneem en as boustene vir die finale gedig van Deuteronomium 32 gebruik.

Die belangrikheid van Deuteronomium 32 vir die Samaritaanse teologie, hou waarskynlik verband met hoe hulle Deuteronomium 32 verstaan het. Preuss (1982: 165) tipeer dit as 'Zusammenfassung der Weisung des Mose.' Waar Moses die groot leerfiguur van die Samaritane is (Montgomery 1968:225), kan dit nie anders nie as dat die leer van Moses en wel soos dit in Deuteronomium 32 in verkorte vorm weergegee word, 'n belangrike plek in die Samaritaanse denke inneem. Wright (1962:40) en Nielsen (1983:86) is daarvan oortuig dat Deuteronomium 32 van noordelike oorsprong is. Alt (1953:417) en Clements (1965:312) kom ook tot die konklusie dat Deuteronomium in Noord-Israel ontstaan het en dat dit met verloop van tyd in Jerusalem beland het waar dit verder verwerk is om by die nuwe omstandighede aan te pas.

Wat die Deuteronomistiese eis van die sentralisasie van die kultus betref, sê Clements (1965:312) dat Deuteronomium nêrens eksplisiet Jerusalem as die sentrale heiligdom aandui nie: 'It is very likely that they believed in some kind of cultic succession in which Shiloh was regarded as the first dwelling-place of Yahweh's name in Canaan, being followed by Jerusalem after the destruction of the former sanctuary.' Dumermuth (1958) wys egter daarop dat Deuteronomium 12:5 deur vele geinterpreteer is as 'n verwysing na die heiligdomme by Sigem, Bet-El of selfs Gibeon. Dumermuth (1958:79) maak egter 'n definitiewe keuse: 'Wir beschränken uns darauf, die Mōglicheit einer Deutung der deuteronomischen Kultformel auf das Heiligtum von Bethel auf ihren Wahrscheinlichkeitsgrad hin zu untersuchen.' Daar bestaan dus geen duidelikheid oor die spesifieke plek waar die sentrale heiligdom waarvan Deuteronomium 12:5 praat, moes wees nie. Dit is veilig om te sê dat die heiligdom waarna Deuteronomium 12:5 corspronklik verwys het, êrens in Noord-Israel was.

Nielsen (1983:90) werp ook lig op die prominente rol wat die Moses-figuur binne die Samaritaanse denke speel wanneer hy stel dat die tradisies oor Moses hulle oorsprong by die noordelike stamme het. Dit kan as verklaring dien waarom die Samaritane soveel waarde aan Moses as kultusleier heg (Montgomery 1968:225; MacDonald 1964:149). As die Samaritane hulle herkoms na die Noord-Israelitiese stamme terugvoer, dan sal dit vanselfsprekend wees dat die Noord-Israelitiese tradisies baie invloed 
op die Samaritaanse denke sou hê. MacDonald (1963:149) wys op die rol wat Deuteronomium 32-34 in Samaritaanse denke oor Moses speel: Daar is geen ander profeet soos Moses nie (Deut 34:10) en die hemel en aarde is aan Moses gehoorsaam (Deut 31: 30-32:1). In die liturgie van die Shemini Aseret-fees kom die belydenis van Moses as onvergelykbare profeet voor (Cowley 1909:784 reël 6): אלהי נבי דלא קעם כמו ('Die God van die profeet wie se gelyke daar nog nie tevoorskyn gekom het nie').

Die rol wat Deuteronomium 32 in die Samaritaanse denke speel, is nog nie genoegsaam nagevors nie. Wat egter wel duidelik is, is dat groot dele van die boek Deuteronomium, waaronder Deuteronomium 32, heelwat trekke van Noord-Israelitiese tradisies vertoon. Die Samaritane se gebruik van die boek Deuteronomium gee ' $n$ aanduiding van die waarde wat die Samaritane aan die Noord-Israelitiese tradisies heg. Die volgende is voorbeelde uit die Shemini Aseret-liturgie (Cowley 1909):

* Deuteronomium 11:21 in Cowley 780 reël 22 en 783 reël 12;

* Deuteronomium 16:9-17 in Cowley 782 reël 19;

* Deuteronomium 26:2-15 in Cowley 782 reêl 34, 791 reël 1-23, 792 reël 25-31, 795 reël 18-31 en 812 reēl 4-9;

* Deuteronomium 32:39 in Cowley 780 reel 24;

* Deuteronomium 32:40 in Cowley 780 reël 27;

* Deuteronomium 32:39-40 in Cowley 783 reël 19;

* Deuteronomium 33:2 in Cowley 784 reël 6-7;

* Deuteronomium 33:29 in Cowley 782 reäl 1 en 784 reël 20;

* Deuteronomium 33:27 in Cowley 783 reë 21-22;

* Deuteronomium 34:10 in Cowley 784 reël 6.

Die Samaritane identifiseer hulle kennelik met Noord-Israelitiese tradisies en gebruik van dié materiaal wanneer hulle oor hulle verhouding met יהוה praat.

\section{KONKLUSIE}

Die Godsbegrip van die Samaritane werp lig op die Samaritane se selfverstaan. יהוה word onder andere as die Skepper-God aanbid. Dit is יהוה wat alle sienlike en onsienlike dinge geskape het. Daar is geen punt van ontstaan en geen punt waar יהוה sal ophou bestaan nie. Hy is die Almagtige. Hy word besing as die Een aan wie alle krag behoort. Die Samaritaanse Godsbegrip is dus absoluut monoteisties.

Baie van die titels en attribute wat die Samaritane aan יהוה toeskryf, is afkomstig uit die Pentateug. Baie van die titels en attribute is aanhalings uit die boek Deuterono- 
mium. In die studie is geargumenteer dat groot dele van die boek Deuteronomium van Noord-Israelitiese afkoms is. Op grond van die Samaritane se gebruik van die boek Deuteronomium, kan afgelei word dat die Samaritane die Noord-Israelitiese tradisies nagevolg het (Bowman 1959a:11). Bowman (1959a:16) sê daarom tereg: ' $\ldots$ the Samaritans ... in all this following Deuteronomy, may on these points be true successors of the best in North Israelite religion.'

Die wyse hoe die Samaritane oor hulle voorvaders praat, die identifisering van die Samaritaanse priesterlyn en die feeste wat die Samaritane herdenk, gee ook aanduidings van die identiteit van die Samaritane, want die manier waarop 'n volk oor sy verlede praat, dui aan hoe hulle hulle eie identiteit in die hede verstaan (Jeismann 1985:13). Kaiser (Kaiser 1993:91) stem ook hiermee saam wanneer hy sê: 'Auch seiner Gottesgewissheit kann der Mensch nur im Horizont seiner konkreten Lebens- und Welterfahrung Ausdruck verleihen.'

Die Samaritane identifiseer hulleself as nakomelinge van Abraham, Isak, Jakob en Josef. Die feit dat Josef as een van die Samaritaanse patriarge geidentifiseer word, is 'n aanduiding van waar hulle sentimente lê teenoor dié van die Jode. Ook wat die priesterskap en priesterlike afkoms betref, is daar ander aansprake as die wat gegeld het by die na-eksiliese Jodedom.

Die feeste wat deur die Samaritane gevier word, is 'n verdere aanduiding van die identiteit van die Samaritane. Die feeste word telkens teruggevoer na corspronge wat nie (meer) die gronde vir die feeste in Israel is nie. Die Samaritane volg dus waarskynlik ouer tradisies wanneer hulle hulle religieuse feeste begrond. Purvis (1986:83) laat hom daarom tereg soos volg uit oor die herkoms van die Samaritane: '[T]he Samaritans claim to be the descendants of the ancient Joseph tribes and the Levitical priests who have lived in Shechem and its environs since the days of the Israelite settlement in Canaan.'

Bowman (1959a:11; 1959b:44) maak ook 'n saak daarvoor uit dat die Samaritane wel van Noord-Israelitiese afkoms is. Hy sê naamlik '[T]o a great extent they were of Israelite stock' (Bowman 1959a:11). Net so maak MacDonald (1963:4) en Gaster (1913:199) albei 'n saak daarvoor uit dat die Samaritane hulle herkoms met reg na Noord-Israel terugvoer.

Die aansprake wat die Samaritane oor hulle herkoms maak, word bevestig deur verskillende elemente in hulle liturgiese tekste. Hulle selfverstaan lê (teenoor die naeksiliese Jodedom se bewerings) volledig in die trajek van 'n Noord- of liewer oudIsraelitiese monoteistiese Jahwisme. Wanneer daar dus oor die identiteit van die Samaritane gepraat word, kan nie volstaan word met hoe die Joodse kanon hulle teken nie. 


\section{Literatuurverwysings}

Alt, A 1953. Die Heimat des Deuteronomiums, in Hermann, S, Grundfragen der Geschichte des Volkes Israel, 392-417. München: CH Beck.

Bell, R H 1994. Provoked to jealousy: The origin and purpose of the jealousy motif in Romans 9-11. Tübingen: JCB Mohr (Paul Siebeck).

Beyers, J \& Breytenbach, A P B 1995 . 'n Vergelykende studie tussen 'n gedeelte uit die Samaritaanse Liturgie en verwante gedeeltes in die Pentateug. HTS 51/4, 900930.

Bowman, J 1959a. The Samaritans and the book of Deuteronomy: Transactions of the Glasgow University Oriental Society XVII, 9-18.

1959b. The importance of Samaritan researches. The Annual of Leeds University Oriental Society 1, 43-54.

Clements, R E 1965. Deuteronomy and the Jerusalem cult tradition. VT 15, 300-312.

Coggins, R J 1991. The Samaritans and Northern Israelite tradition. Proceedings of the International congress Societe d'Etude Samaritaines 1, 99-108.

Cowley, A E (ed) 1909. The Samaritan Liturgy, Vol 2. Oxford: Clarendon.

Cross, F M 1980. Canaanite myth and Hebrew epic: Essays in the history of the religion of Israel. London: Harvard University Press.

Crown, A D (ed) 1989. The Samaritans. Tübingen: JCB Mohr.

Deist, F 1989. A concise dictionary of theological and related terms. Pretoria: Van Schaik.

Deurloo, K A 1986. Exegese naar Amsterdamse traditie, in Van der Woude, A S (red) Inleiding tot de studie van de Ou Testament, 188-198. Kampen: Kok.

De Vaux, R 1988. Ancient Israel, its life and institutions. London: Darton, Longman and Todd.

De Vries, S J 1989. s v calender. IDB, Vol 1.

Dumermuth, F 1958. Zur deuteronomistischen Kulttheologie und ihren Voraussetzungen. ZAW 70, 59-98.

Epstein, I 1959. Judaism, a historical presentation. London: Penguin Books.

Gaster, M 1913. The feast of Jeroboam and the Samaritan calendar. The Expository Times 24, 198-201.

Green, L C 1958. A critical edition and translation of the Samaritan feast of $\mathrm{Hag} \mathrm{Ha}$ Succoth with special reference to the historical development involved, Part I \& II. DD Dissertation, University of Leeds.

Jeismann, K-E 1985. Geschichte als Horizont der Gegenwart; Ober den Zusammenhang von Vergangenheitsdeutung, Gegenwartsverstandnis und Zukunftsperspektive. Paderborn: Ferdinand Schöningh.

Johnson, R F 1989. s v Caleb. IDB, Vol 1.

Kaiser, O 1993. Der Gott des Altes Testaments. Göttingen: Vandenhoeck \& Ruprecht. 
Kippenberg, H G 1971. Garizim und Synagogue: Traditionsgeschichtliche Untersuchungen zur samaritanische Religion der aramaische Periode. Berlin: Walter de Gruyter.

Kraus, H-J 1966. Worship in Israel: A cultic history of the Old Testament. Oxford: Blackwell.

Labuschagne, C J 1971. The Song of Moses: Its framework and structure, in De Fructu Oris Sui: Essays in honour of Adrianus van Selms, 85-98. (Pretoria Oriental Series.) Leiden: E J Brill.

Lowy, S 1977. The principles of Samaritan Bible exegesis. Leiden: EJ Bril.

Luyten, J 1985. Primeval and eschatological overtones in the Song of Moses (Dt 32:1 -43) in Lohfink, N, Das Deuteronomium: Entstehung, Gestalt und Botschaft, 341347. Leuven: Peeters.

MacDonald, J 1963. The Samaritan day of atonement liturgy, with selected translations. Leeds: Leeds University Oriental Society.

MacDonald, J 1964. The theology of the Samaritans. London: SCM.

Macuch, R 1991. The importance of Samaritan tradition for the hermeneutics of the Pentateuch. Proceedings of the International congress Societe d'Etude Samaritaines 1, 13-31.

Montgomery, J A 1968. The Samaritans: The earliest Jewish sect: Their history, theology and literature. New York: KTAV.

Nielsen, E 1983. Law, history an tradition, selected essays by Eduard Nielsen. Kopenhagen: GEC Gads Forlag.

Preuss, H D 1982. Deuteronomium. Darmstadt: Wissenschaftliche Buchgesellschaft.

Purvis, J D 1986. The Samaritans and Judaism in Kraft, R A \& Nickelsburg, W E, Early Judaism and its modern Interpreters, 81-98. Philadelphia: Fortress.

Rylaarsdam, J C 1989. s v booths, feast of. IDB, Vol 1.

Wintermute, O S 1989. s v Joseph son of Jacob. IDB, Vol 2.

Wright, G E 1962. The lawsuit of God: A form-critical study of Deuteronomy 32 in Israel's prophetic heritage. Essays in honor of James Muilenburg. New York: Harper and Brothers. 